\title{
Loss of basal feet on Odf2 deletion perturbs polarization of basal bodies
}

\author{
K Kunimoto ${ }^{1 *}$, YY Yamazaki ${ }^{1}$, TN Nishida ${ }^{2}$, KS Shinohara ${ }^{3}$, HI Ishikawa ${ }^{4}$, TH Hasegawa ${ }^{2}$, TO Okanoue ${ }^{5}$, HH Hamada ${ }^{3}$, \\ TN Noda ${ }^{6}$, AT Tamura', ST Shoichiro Tsukita ${ }^{1,7}$ \\ From First International Cilia in Development and Disease Scientific Conference (2012) \\ London, UK. 16-18 May 2012
}

Synergic multiciliary beating relies on cilia generated from basal bodies, with which basal feet are regularly associated through molecular mechanisms that remain unknown. Here we show that the coordinated multiciliary action is disturbed in Odf2 mutant mice, resulting in primary ciliary dyskinesia and a characteristic coughing/ sneezing-like phenotype. Odf2-deficiency depleted basal feet from basal bodies to perturb the planar cell polarity (PCP) of basal bodies, as shown by ultra-high voltage electron microscopic tomography (UHVEMT) of wild and Odf2 mutant tracheas. The apical microtubular lattice, which is organized by the keystone positioning of basal feet/basal bodies, was lost in Odf2-mutant animals, irrespective of normal localization of Vangl1, the PCP core protein. These findings demonstrate that Odf2 is required for the formation of basal feet. Odf2-based basal feet play a critical role in the PCP-based arrangement of the microtubular lattice and basal bodies, thereby enabling coordinated multiciliary beating.

\footnotetext{
Author details

'Laboratory of Biological Science, Graduate School of Frontier Biosciences and Graduate School of Medicine, Osaka University, Japan. ${ }^{2}$ Research Center for Ultra-high Voltage Electron Microscopy, Osaka University, Japan. ${ }^{3}$ Developmental Genetics Group, Graduate School of Frontier Biosciences, Osaka University and CREST, Japan Science and Technology Corporation (JST), Japan. ${ }^{4}$ Department of Biochemistry and Biophysics, University of California, San Francisco, USA. ${ }^{5}$ Department of Hepatology, Saiseikai Suita Hospital, Osaka, Japan. ${ }^{6}$ Department of Cell Biology, Cancer Institute of Japanese Foundation for Cancer Research, Tokyo, Japan. ${ }^{7}$ Department of Cell Biology, Faculty of Medicine, Kyoto University, Japan.
}

Published: 16 November 2012

\footnotetext{
* Correspondence: k-kunimoto@biosci.med.osaka-u.ac.jp

'Laboratory of Biological Science, Graduate School of Frontier Biosciences and Graduate School of Medicine, Osaka University, Japan

Full list of author information is available at the end of the article
}

doi:10.1186/2046-2530-1-S1-026

Cite this article as: Kunimoto et al.: Loss of basal feet on Odf2 deletion perturbs polarization of basal bodies. Cilia 2012 1(Suppl 1):O26.
Submit your next manuscript to BioMed Central and take full advantage of:

- Convenient online submission

- Thorough peer review

- No space constraints or color figure charges

- Immediate publication on acceptance

- Inclusion in PubMed, CAS, Scopus and Google Scholar

- Research which is freely available for redistribution

\section{() Biomed Central}

C Biomed Central

(C) 2012 Kunimoto et al; licensee BioMed Central Ltd. This is an Open Access article distributed under the terms of the Creative Commons Attribution License (http://creativecommons.org/licenses/by/2.0), which permits unrestricted use, distribution, and reproduction in any medium, provided the original work is properly cited. 